\title{
Analysis of Sharia Banking Efficiency in Industry Revolution 4.0 Era
}

\author{
Reny Fitriana Kaban ${ }^{1 *}$, Novita Setyawati ${ }^{2}$
}

${ }^{12}$ Perbanas Institute, Jakarta Selatan, Indonesia

\section{A R T I C L E I N F O}

Article history:

Received 01 October 2020

Received in revised form

14 October 2020

Accepted 30 October 2020

Available online 01

November 2020

Keywords

Sharia Banking, Efficiency

\begin{abstract}
A B S T R A C T
This research aimed to analyze the efficiency of Sharia Banking in Indonesia for the period of 2013-201, the era of industry revolution 4.0. The research method used Data Envelopment Analysis while the data was taken from the annual report of Sharia Banking Statistic issued by Indonesia Financial Services Authority for the intended years. The input variables were the third-party fund, labor cost, and other cost while the output variables were total financings and operating income. Both with CRS and VRS model input approach, Sharia Banking in Indonesia generally already had high-efficiency value either based on years or banks. The banks who had not been in high-efficiency criteria were highly recommended learning from the benchmark banks. The result showed in general the use of technology and the internet by Sharia Banking was already appropriate, which caused their operations running efficiently.
\end{abstract}

Copyright (C) Universitas Pendidikan Ganesha. All rights reserved.

\section{Introduction}

Islamic Finance Development Report from Thomson Reuters, Indonesia's Sharia financial market growth was in 10th place out of 131 countries with a score of 50, while Malaysia was in first place with a score of 132 (Novaindra, 2014; Widowati, 2019). Considering Indonesia is the largest Moslem population country in the world, it should be in the top rank. It is indicated that the slow growth of the Islamic financial market in Indonesia is due to the inefficient operation of Sharia banks. Given data from Indonesia Financial Services Authority (OJK), for the period 2017-2019 shows that Sharia Banking (SB) industry had an unstable level of efficiency. Net Interest Margin (NIM) ratio has increased but still not reached the ideal number, above 6\%, according to (Peraturan Bank Indonesia Nomor: 7/2/PBI/2005 Tentang Penilaian Kualitas Aktiva Bank Umum, 2005), while the Operating Expense Ratio (OER) ratio has decreased but also still not reached the ideal number, below 75\%, according to (Peraturan Bank Indonesia Nomor: 13/ 1 /PBI/2011 Tentang Penilaian Tingkat Kesehatan Bank Umum, 2011). For this slow performance, SB needs to strengthen capital, maintain liquidity, and increase the efficiency (Hastuti, 2019).

Table 1. Sharia Banking Financial Ratio in 2017-2019

\begin{tabular}{ccc}
\hline Year & NIM (\%) & OER (\%) \\
\hline 2017 & 5.08 & 107,45 \\
2018 & 5.72 & 103,71 \\
2019 & 5.97 & 88,88 \\
\hline
\end{tabular}

Meanwhile, based on data from the SB Statistics, the asset's quality of SB is still under the Conventional Banking (CB). At the end of March 2019, NPF of SB, 3.44\%, was higher than NPL of CB, 2.5\% (OJK, 2019). Moreover, at the end of December 2018, the Return on Assets (ROA) of SB, 1.28\%, was lower than $\mathrm{CB}, 2.55 \%$. These facts show that $\mathrm{SB}$ is unable to compete with $\mathrm{CB}$. This cannot be denied considering the market share of SB is still 5\%. Therefore, BI is targeting in 2023 SB industry will reach a market share of $20 \%$ (Sebayang, 2018).

To reach the target SB is encouraged to innovate and continue developing. Because the rival is not only the CB but also the Financial and Technology (fintech) industry (Masduki, 2019). On the other hand, 
past literature has identified technological innovation as a key indicator of bank efficiency and productivity (Al-halawani, 2019). Technology and the internet are the functions of the Industrial Revolution 4.0. Klaus Schwab mentioned it will affect the core experience of a human being. It will have an impact on speed, breadth, and depth as well as systemic impacts on the country, society, industry and companies with the concept of physical megatrend (Dadan, 2019). In this era, when transacting with banks, customers have the expectations of getting faster, easier, more innovative, and even cheaper products. This is a challenge for SB to meet those expectations besides reaping the revenues. As economist, Sipler, argues that financial innovation is the most positive for financial institutions to maximize profits (Yang \& Qi, 2017). Hence, adopting technology for commercial banks remains them competitive (Gichungu \& Oloko, 2015) sustainable, and efficient.

Regarding to bank efficiency, Matthews \& Ismail in Dadang, et al (2014) describe the efficiency of banking is closely related to the efficiency of the banking market, the intermediation process, and efficiency in implementing monetary policy through regulation of bank loans. The production and intermediation approaches in measuring bank efficiency has difference in determining input and output. In the production approach, savings as output, because they are produced by bank activities. Meanwhile, in the intermediation approach, savings as input, because they will flow to various loans. As an intermediary institution, SB must be able to allocate third-party funds (TPF) in their more productive sectors financing optimally to produce maximum output, so efficiency will be created. Technical Efficiency (TE) refers to maximizing output at existing costs. A company is said to be TE if it can produce more output by using a certain number of inputs compared to other companies (Yotopulas and Lau in Rusydiana (2019)). Apart from TE, there is also Allocation Efficiency (AE) which reflects the company's ability to use inputs in optimal proportions. The two efficiencies produce Combined Efficiency (CE) which provides a measure of the company's cost-efficiency. The efficiency value is limited between zero and one (Gordo, 2013).

A method for calculating efficiency is Data Envelopment Analysis (DEA). It is an established relative efficiency analysis technique in banking (Avkiran, 2011). DEA is a procedure specifically designed to measure efficiency values that use many inputs and outputs. The relative DEA efficiency score depends on its level of other Sharia banks in the sample. DEA can provide recommendations on what factors must be changed to achieve efficiency (Amirillah, 2014).

There are previous studies analyzing the efficiency of SB in Indonesia using the DEA or nonparametric approach. Amirillah (2014) with input variables such as current account, savings, and deposits also paid-up capital, found the average efficiency value of SB in the 2005-2009 period was 99,94\%. In the same year, Novaindra (2014) with the same input variables compared SB and CB for period research 2008-2013 (post-global crisis), and found out that SB is more efficient. Pambuko (2016) with different input variables such as TPF and capital fund found out that the level of efficiency of SB in Indonesia in the 2010-2013 period shows a fluctuating trend and inefficient category. In the next year, Ramly \& Hakim (2017) made a model of Bank Efficiency in Indonesia and Comparison between SB and CB for period research 2012-2104. The next research was conducted by Rusydiana (2018), with input variables TPF and labour cost and found out the average value of the CRS efficiency of SB in Indonesia is relatively low, 66\% in the 2007-2014 period. This study repeats Rusdiyana's research for the same input and output variables but specifically analyzes the year 2013-2019 as the years of the industry revolution 4.0.

Meanwhile previous studies thoroughly discuss about bank efficiency in 4.0 era with DEA method have not been done, but some investigated the effect of IT on bank efficiency. Dangolani (2011) and Ahmadirezaei (2011) indicate that IT can reduce operational cost for banks in Iran. While Appiahene, et.al (2019) researched DEA method suggested that IT had significant impact on Ghana banks overall performance, most of them were efficient in their entire operations. It goes with the empirical findings of Romdhane (2013) which suggests the impact of IT investments on Tunisian banks' performance is positive. But Ho \& Mallick (2010) found the opposite results which suggest that individual USA bank profits can decline due to adoption and diffusion of IT investment which reflects negative network competition effects in this industry.

Based on current SB problems such as the slow growth, high target of market share and tight competition with $\mathrm{CB}$ and fintech industry, this research attempts to solve those problems through analyzing bank efficiency concept. Empirical researches about efficiency of SB and the effect of technology and the internet to bank efficiency have different results however by this research renewable data and output is formulated. This study aims to analyze the efficiency of SB in Indonesia during the period 20132019, the industrial era 4.0 using the DEA method. The results of this study are expected as reference for SB which trying to improve operational efficiency for having sustainable performance and competitive advantage. 


\section{Methods}

The secondary data obtained from the financial balance and profit and loss statements of each SB, published by the OJK, analyzed by DEA. There were $11 \mathrm{SB}$ as the population for DMU or research unit used in this research. The 2013-2019 period research is as the industrial revolution 4.0 era.

The input variables are TPF, labor costs, and other costs (administrative and general costs), while output variables are total financing and operating income. This study uses two efficiency measurement models in DEA. The first is the CRS model, the second is the VRS model. CRS model was developed first by Charnes, Cooper, and Rhodes (CCR) in 1978 (Inel, 2019). The input-oriented model assumes of a constant return to scale so it is known as the CRS model. In the CRS model, each DMU will be compared with all DMUs in the sample, assuming that the internal and external conditions of the DMU are the same (Cooper et al., 2011). According to Casu \& Molyneux (2003), the CRS model which has the appropriate assumption is used only when all DMUs operate at an optimal scale. As a result, the use of the CRS model when several DMUs do not operate at the optimal scale will result in inappropriate technical efficiency due to inappropriate scale efficiency. The concept of this model approach is constant return to scale, which means that the addition of one input must add one output. If the input is increased by $x$ times, the output will also increase by $\mathrm{x}$ times.

The weakness of the CRS assumption raises another assumption, which is a variable return to scale (VRS). This model was first introduced by Banker, Charner, and Cooper, so this model is known as the BCC model (Banker et al., 1984). This assumption model is a variable return to scale, which means that additional $\mathrm{x}$ times of input will not cause the output to increase $\mathrm{x}$ times, it can be smaller or larger. This approach is relatively more appropriate to use in analyzing the performance efficiency of service companies, including banks. According to Avkiran (1999), VRS is an assumption that is more appropriate to use for large samples. VRS describes the overall technical efficiency which consists of two components: pure technical efficiency and scale efficiency. Pure technical efficiency describes the ability of company managers or DMUs to utilize their resources. Meanwhile, scale efficiency describes a DMU or company that can operate at the right production scale.

Measuring data using DEA can use two approaches first is Input and second Output Approach. The Input Approach shows that the number of inputs can be reduced proportionally without changing the amount of output produced. By using this approach, the model will calculate the input reduction needed to produce efficient performance with fixed output. Fethi \& Pasiouras (2010) revealed that the banking industry uses this approach assumed that bank managers will have higher supervision or control over inputs (such as employee expenses) than outputs (such as credit and income). According to Casu \& Molyneux (2003), some studies tend to choose input approach because the number of inputs is the main decision in making variables, although this reason does not apply to all industries. To determine or ensure the level or stage of efficiency of SB, efficiency measures or criteria are made, namely high $(0,81-1)$, moderate $(0,6-0,8)$, low $(0,4-0,59)$, and inefficient $(<0,4)$ (Hidayat, 2014). Research data validation was carried out using Microsoft Excel, for calculating the DEA efficiency score using the Efficiency Measurement System (EMS) software version 1.3.

\section{Results and Discussions}

The results of overall efficiency analysis on 11 SB in Indonesia in the industrial revolution era 4.0 using DEA method, CRS model, Input approach, found that the efficiency value has increased from year to year, and reached peak in 2018 of $92.66 \%$. However, the value declined quite sharply in 2019 by $78.20 \%$ (see Figure 1). Referring to criteria and efficiency value for SB in Indonesia (Hidayat, 2014), only in 2016 (79.02\%) and 2019 (78.2\%) has moderate efficiency, which is between 0.6-0.8, in other years SB are highly efficient because the value is above $80 \%$.

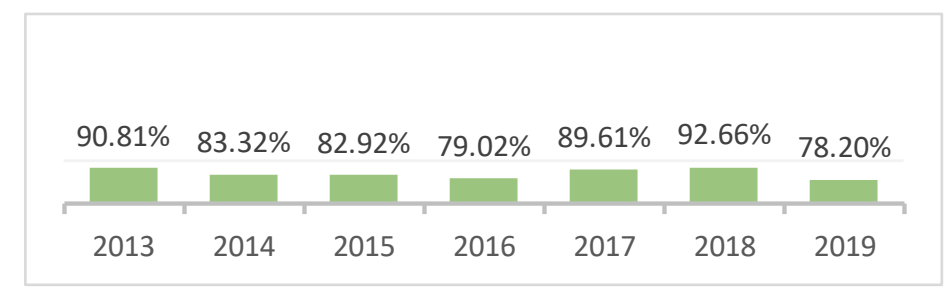

Figure 1. Average Sharia Banking Efficiency Value in Indonesia Based on Years with CRS Model Input Approach 
Meanwhile, the average efficiency value of each SB was around 60\% $-100 \%$. BBMI, BBNIS, and BBRIS still have moderate efficiency criteria, because their values are between $60 \%-80 \%$ while 8 other banks have entered the high-efficiency criteria because their efficiency values are above $80 \%$. Determination of efficiency between DMUs uses a reference set approach. The reference set is representative of DMUs compared to other benchmarks DMUs which has an efficiency value $100 \%$. DMUs with efficiency less than $100 \%$ can learn from benchmark DMU how to transfer input to output to be more efficient. The benchmark banks are BBPS and BBVS for efficiency value of $100 \%$.

If the overall efficiency of SB averaged from 2013 to 2019 the value would be $85 \%$. Referring to the efficiency criteria, it is high. The results of this study follow up on previous research conducted by Rusydiana (2018), which shows that the average value of SB efficiency for the 2007-2014 period with the CRS model for the input approach is moderate, $66 \%$, while in this study the value increases. The CRS model assumes that the ratio between the additions to input to output is the same. If the input is increased by $\mathrm{x}$ times, the output will also increase by $\mathrm{x}$ times. Another assumption of this model is that each bank has operated at an optimum scale. Thus, to increase the efficiency value to $100 \%$, it is necessary to add input of $100 \%-85 \%$. By this efficiency finding, SB is confirmed for being able to allocate TPF in their financing into more productive sectors, it means its intermediary process has accomplished (Dadang et al., 2014)

The results of efficiency analysis using the VRS model, Input approach found that the average efficiency value was relatively stable with a range of $92 \%-98.8 \%$ (see Figure 2). For the entire years it was $94.93 \%$. Referring to the efficiency criteria, it is high efficiency because above $80 \%$. Compared to CCR value, the VRS is higher. This is due to the assumption with the VRS model, the ratio between the addition of input and output is not the same. Increasing the input $x$ times will not cause an increase in output $x$ times, it may be smaller or greater than $x$ times. Thus, to increase the level of efficiency of SB from $94 \%$ to $100 \%$ does not necessary to increase the input by $100 \%-94 \%$, because this does not guarantee that the efficiency level will increase as much as the increase of inputs.

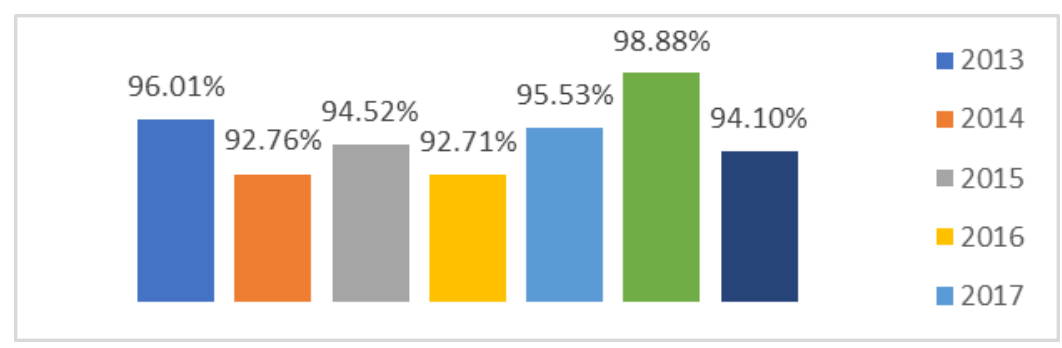

Figure 2. Average Sharia Banking Efficiency Value in Indonesia Based on Years with VRS Model Input Approach

There are 5 banks, BBMI, BBMSI, BBJBS, BBPS, and BBVS have achieved full efficiency. All these Banks can become the benchmark for other banks that have not reached it. In other words, the other six banks, especially BBRIS, which still has moderate efficiency criteria, can adopt policies and business strategies to achieve efficiency in the financial performance of the five banks, especially those related to input management. Since the model is using input approach, therefore supervising the use of input variables such as TPF, labor costs and other costs persistently is more recommended than the output variables (Fethi \& Pasiouras, 2010)

Again, with the VRS model, the efficiency value of each bank is higher than using the CRS. The VRS model is relatively more appropriate in analyzing the performance of bank efficiency for large samples (Avkiran, 1999). Since this sector produces services through human labor, it is highly influenced by external factors, so it is rather difficult to know whether it has operated at an optimal scale or not if only use the CRS model whose evaluation results are on "overall efficiency" while with VRS has separated "technical efficiency" and "scale efficiency" (Abidin et al., 2008). The results of the study which showed that the efficiency value of the VRS technique was higher than the CRS in line with research conducted by (Hidayat, 2014).

The industrial revolution 4.0 era is a trend in industrial banking world that combines automation technology with a physical cyber system that allows connecting devices to the internet network (MIX Marketing \& Communication, 2019). This means SB and CB are inevitably required to use technology and the internet (digitalization) in their business operations. Because by adopting them, producing process of services will become much easier. In addition to the convenience benefits, much of idle time to think about 
the next innovation and the remaining costs can be allocated for business development. A common example for IT in this era is internet banking and mobile banking services to facilitate customers making transactions with banks. A sophisticated technology applied by Banks to interact with its customers is chatbot technology, a chat application. Several banks have implemented this technology are BNI with Cinta and BCA with Vira. This virtual assistant service is used as a substitute for bank customer service. Viewed from the banking side, this technology can make operational costs more efficient, especially labor costs and other costs significantly. This is evidenced by the result of this research which shows that the two banks have a good OER ratio because already under the maximum efficiency ratio, 93.25\% according to BI Regulation No.13/1/PBI/ 2011 (Peraturan Bank Indonesia Nomor: 13/ 1/PBI/2011 Tentang Penilaian Tingkat Kesehatan Bank Umum, 2011). The average OER ratio of each bank can be seen in Figure 3 below.

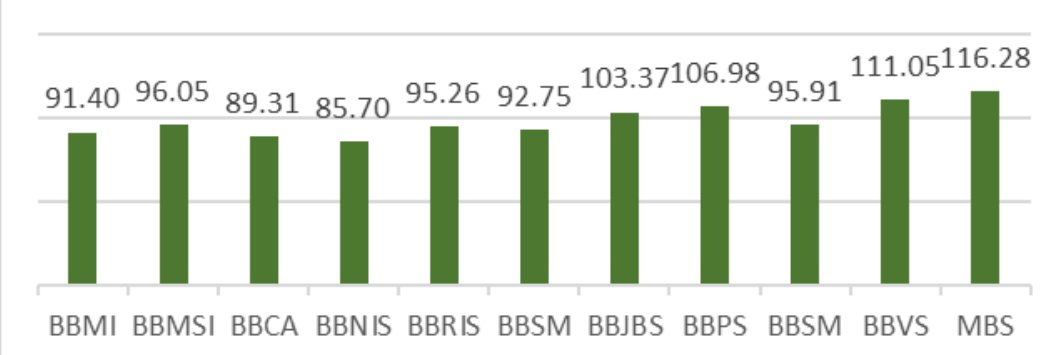

Figure 3. Average OER Ratio Sharia Banks in Indonesia for 2013-2019 Period

Overall, for the result of this research about how IT affects the bank efficiency confirms other previous researches from (Ahmadirezaei, 2011; Dangolani, 2011) which explain through IT can reduce operational cost. Moreover, this research also goes along with (Appiahene et al., 2019; Romdhane, 2013) which suggest IT had significant impact on bank efficiency but not with (Ho \& Mallick, 2010) findings which reflect negative relation between adopting IT and bank efficiency. As adopting the IT caused high efficiency, SB in this revolution industry 4.0 era appears to be more competitive (Gichungu \& Oloko, 2015) and generate maximum profit (Yang \& Qi, 2017).

\section{Conclusion}

The efficiency value of Sharia Banking in Indonesia in the industrial era 4.0 is still fluctuating both analyzed using the CRS and VRS models with the input approach. With VRS model, SB efficiency is in high criteria which shows that adopting technology and the internet affects bank efficiency. However, instability and fluctuation of bank efficiency value need to be monitored and anticipated carefully. Sharia Banks should further improve their innovation by maximizing IT since adopted digitalization technology has proven significantly reduce operational costs which in turn have an impact on sustainable performance in the future. Regulators should provide policies that support SB to innovate in IT, but remain prudent in terms of banks and customers protection. For further research, capital cost in investment on IT are suggested as input variable to analyze the bank efficiency more accurately.

\section{Acknowledgment}

This paper is based upon work supported by Kemenristek DIKTI Indonesia Research Award 2020, Contract Number 079/SP2H/AMD/LT/DRPM/2020. We are grateful for the support. Published paper in the International Journal is our responsibility for the grants given.

\section{References}

Abidin, Z., Endri, \& Nirmalawati, D. (2008). Kinerja Keuangan dan Efisiensi Perbankan: Pendekatan CAMEL, DEA dan SFA. ABFI Institute Perbanas.

Ahmadirezaei, H. (2011). Social and The Effect of Information Technology in Saderat Banking System. Procedia - Social and Behavioral Sciences, 30, 23-26. https://doi.org/10.1016/j.sbspro.2011.10.005 
Al-halawani, O. (2019). The Effects of Innovation on Bank Efficiency and Productivity (Issue August).

Amirillah, A. (2014). Efisiensi perbankan syariah Di Indonesia. JEJAK Journal of Economics and Policy, 7(2), 100-202. https://doi.org/10.15294 jejak.v7i1.3596

Appiahene, P., Missah, Y. M., \& Najim, U. (2019). Evaluation of information technology impact on bank' s performance : The Ghanaian experience. International Journal of Engineering Business Management, 11,1-10. https://doi.org/10.1177/1847979019835337

Avkiran, N. K. (1999). The evidence on efficiency gains: The role of mergers and the benefits to the public. Journal of Banking \& Finance, 23(7), 991-1013.

Avkiran, N. K. (2011). Association of DEA super-efficiency estimates with financial ratios : Investigating the case for Chinese banks. Omega, 39(3), 323-334. https://doi.org/10.1016/j.omega.2010.08.001

Banker, R., Charnes, A., \& Cooper, W. (1984). Some models for estimating technical and scale inefficiencies in data envelopment analysise. Management Science, 30(9), 1031-1142. https://doi.org/https://doi.org/10.1287/mnsc.30.9.1078

Casu, B., \& Molyneux, P. (2003). A comparative study of efficiency in European banking. Applied Economics, 35(17), 1865-1876. https://doi.org/https://doi.org/10.1080/0003684032000158109

Cooper, W. W., Selford, L. M., \& Zhu, J. (2011). Data Envelopment Analysis: History, Models and Interpretations. In: Cooper W., Seiford L., Zhu J. (eds) Handbook on Data Envelopment Analysis. International Series in Operations Research \& Management Science, 164, 1-39. https://doi.org/https://doi.org/10.1007/978-1-4419-6151-8_1

Dadan. (2019). Revolusi Industri 4.0.

Dadang, M., Hafidz, J., Astuti Riska, I., \& Oktapiani, R. (2014). Faktor-Faktor Penetu Efisiensi Perbankan serta Dampaknya terhadap Perhitungan Suku Bunga Kredit.

Dangolani, S. K. (2011). The Impact of Information Technology in Banking System (A Case Study in Bank Keshavarzi IRAN). Procedia-Social and Behavioral Science, 30, 13-16. https://doi.org/https://doi.org/10.1016/j.sbspro.2011.10.003

Fethi, M. D., \& Pasiouras, F. (2010). Assessing bank efficiency and performance with operational research and artificial intelligence techniques : A survey. European Journal of Operational Research, 204, 189198. https://doi.org/10.1016/j.ejor.2009.08.003

Gichungu, Z. N., \& Oloko, M. A. (2015). Relationship between Bank Innovations and Financial Performance of Commercial Banks in Kenya. International Journal of Education and Research, 3(5), 443-456.

Gordo, G. M. (2013). Estimating Philippines Bank Efficiencies Using Frontier Analysis. Philippines Management Review, 20, 17-36.

Hastuti, R. K. (2019, June). Perbankan Syariah Masih Sulit Bersaing Dengan Konvensional. CNBC Indonesia.

Hidayat, R. (2014). Efisiensi Perbankan Syariah: Teori dan Praktek. Gramata Publishing.

Ho, S., \& Mallick, S. (2010). The impact of information technology on the banking industry. Journal of The Operational Research Society

https://doi.org/https://doi.org/10.1057/jors.2008.128

61(2),

211-221.

Peraturan Bank Indonesia Nomor: 7/2/PBI/2005 Tentang Penilaian Kualitas Aktiva Bank Umum, (2005).

Peraturan Bank Indonesia Nomor: 13/ 1 /PBI/2011 Tentang Penilaian Tingkat Kesehatan Bank Umum, (2011).

Inel, M. N. (2019). An empirical study on measurement of efficiency of digital transformation by using data envelopment analysis. Management Science Letters, 9, 549-556. https://doi.org/10.5267/j.msl.2019.1.008

Masduki, A. (2019). Ini Tantangan Perbankan di Era Revolusi Industri 4.0. Sindonews 6 Maret 2019.

MIX Marketing \& Communication. (2019). Industri 4.0 Ketika Dunia dalam Satu Genggaman. Asoka Aksara.

Novaindra, R. (2014). Analisis Perbandingan Efisiensi Perbankan Syariah Dan Konvensional Di Indonesia. Jurnal Ekonomi Dan Pembangunan, 22(2), 183-193. https://doi.org/https://doi.org/10.14203/JEP.22.2.2014.183-193

OJK. (2019). Statistik Perbankan Syariah OJK Kuartal 12019.

Pambuko, Z. B. (2016). Determinan Tingkat Efisiensi Perbankan Syariah Di Indonesia: Two Stages Data Envelopment Analysis. Cakrawala: Jurnal Studi Islam, 11(2), 178-194. 
https://doi.org/10.31603/cakrawala.v11i2.249

Ramly, A. R., \& Hakim, A. (2017). Pemodelan Efisiensi Bank di Indonesia: Perbandingan antara Bank Syariah dan Bank Konvensional. Esensi: Jurnal Bisnis Dan Manajemen, 7(April), 131-148. https://doi.org/10.15408/ess.v7i2.

Romdhane, S. Ben. (2013). Information Technology On The Impact of Perfomance of Tunisian Bank : A Stochastic Frontier Analysis With Panel Data. Asian Academy of Management Journal of Accounting and Finance, 9(2), 95-125.

Rusydiana, A. S. (2018). Efisiensi Dan Stabilitas Bank Umum Syariah Di Indonesia. Akuntabilitas: Jurnal Ilmu Akuntansi, 11(2), 203-222. https://doi.org/10.15408/akt.v11i2.7033

Rusydiana, A. S. (2019). Efisiensi Sosial dan Finansial Bank Syariah di Indonesia: Pendekatan Nonparametrik. Jurnal Riset Akuntansi Dan Keuangan Indonesia, 4(1), 13-25. https://doi.org/https://doi.org/10.23917/reaksi.v4i1.6814

Sebayang, R. (2018). BI Targetkan Industri Syariah Capai Market Share 20\%. CNBC Indonesia.

Widowati. (2019). Indonesia Masuk 10 Negara yang Pasar Keuangan Syariahnya Tumbuh Pesat. Databoks 14 Mei 2019.

Yang, F., \& Qi, Y. (2017). An empirical study on the efficiency of bank innovation in the context of internet financial development. Advances in Economics, Business and Management Research, 33, 931-937. https://doi.org/https://dx.doi.org/10.2991/febm-17.2017.125 